\title{
Faktor yang Berhubungan dengan Status Gizi Anak di TK Islam H.M. Asyik Makassar
}

\author{
Factors Associated with Children's Nutritional Status \\ in H.M. Islamic Kindergarten Asyik Makassar
}

\begin{abstract}
Herman Hatta
Program Studi Ilmu Gizi Universitas Gorontalo e-mail: hattaherman.1988@gmail.com

Abstrak

Status gizi yang baik pencapaiannya tidak hanya dilakukan dengan pendekatan medis dan pelayanan kesehatan saja. Dalam hal ini gizi ternyata sangat berpengaruh terhadap kecerdasan dan perkembangan balita. Agar perencanaan upaya peningkatan status gizi penduduk dapat dilakukan dengan baik, semua aspek yang berpengaruh perlu diteliti, diantaranya adalah program pemberian makanan tambahan, daya beli keluarga, kebiasaan makan balita, pemeliharaan kesehatan keluarga serta pola asuh keluarga. Tujuan penelitian yaitu menetahui faktor yang berhubungan dengan status gizi anak di TK Islam H.M. Asyik Makassar.

Metode penelitian yang digunakan dalam penelitian ini adalah Observasional dengan pendekatan Cross Sectional Study. Populasi dalam penelitian ini adalah semua anak yang ada di TK Islam H.M Asyik Makassar sebanyak 69 anak. Sampel dalam penelitian ini adalah semua anak yang ada di TK Islam H.M. Asyik Makassar yang dipilih dengan cara Exhaustic Sampling (total sampel) sebanyak 69 anak. Analisis data bertahap dari univariat dan bivariat menggunakan uji chisquare.

Hasil penelitian menunjukkan asupan gizi ( $p$ value $=0,000$ ), pengetahuan ( $p$ value $=0,000$ ), dan pendapatan keluarga ( $p$ value $=0,000$ ) berhubungan dengan status gizi anak. Kesimpulan bahwa asupan gizi, pengetahuan, dan pendapatan keluarga berhubungan dengan status gizi anak di TK Islam H.M. Asyik Makassar tahun 2018.

Saran bagi ibu dan pengasuh sebaiknya lebih menambah pengetahuan mengenai gizi anak dan keluarga serta lebih memperhatikan asupan makanan yang di komsumsi oleh anak, agar status gizi anak berada dalam ketegori status gizi baik.

aspects need to be studied, including the provision of supplementary feeding programs, family purchasing power, toddler eating habits, maintaining family health and family care. The purpose of the study was to determine the factors related to the nutritional status of children in Islam H.M.Asyik Makassar Kindergarten.

The research method used in this study is Observational with a Cross Sectional Study approach. The population in this study were 69 children in Islam H.M. Asyik Makassar Kindergarten. The sample in this study were all children in Islam H.M. Asyik Makassar Kindergarten who were selected by Exhaustic Sampling (total sample) of 69 children. Gradual data analysis from univariate and bivariate using the chisquare test.

The results showed nutritional intake ( $p$ value $=0.000)$, knowledge ( $p$ value $=0.000)$, and family income ( $p$ value $=$ $0.000)$ related to children's nutritional status. The conclusion is that nutritional intake, knowledge, and family income are related to the nutritional status of children in Islam H.M. Asyik Makassar Kindergarten in 2018.

Suggestions for mothers and caregivers should be to increase knowledge about child nutrition and family and pay more attention to food intake consumed by children, so that the nutritional status of children is in the category of good nutritional status.

Key word: Child nutritional status, nutritional intake, knowledge, family income

\section{Pendahuluan}

Masalah kekurangan konsumsi pangan
\end{abstract}

Kata Kunci : Status gizi anak, asupan gizi, pengetahuan, pendapatan keluarga

\section{Abstrack}

Good nutritional status is not only achieved through medical approaches and health services. In this case nutrition turned out to be very influential on the intelligence and development of toddlers. In order to make the planning of efforts to improve the nutritional status of the population well, all influential bukanlah merupakan hal baru, namun masalah ini tetap aktual terutama di negara-negara sedang berkembang contohnya Indonesia. Sebab akan mempuyai dampak yang sangat nyata terhadap timbulnya masalah gizi.

Status gizi yang baik pencapaiannya tidak hanya dilakukan dengan pendekatan medis dan pelayanan kesehatan saja. Dalam hal ini gizi ternyata sangat berpengaruh terhadap 
kecerdasan dan perkembangan balita. Agar perencanaan upaya peningkatan status gizi penduduk dapat dilakukan dengan baik, semua aspek yang berpengaruh perlu diteliti, diantaranya adalah program pemberian makanan tambahan, daya beli keluarga, kebiasaan makan balita, pemeliharaan kesehatan keluarga serta pola asuh keluarga.

Berdasarkan data UNICEF pada tahun 2012 bahwa jumlah anak balita yang mengalami kurang gizi terdapat kurang lebih 2,9 miliar jiwa. Pada tahun 2010 jumlah balita Indonesia $10-12$ juta $(69 \%)$ berstatus gizi buruk yang mengakibatkan kematian. Di Indonesia setiap tahun diperkirakan 7\% anak balita meninggal. ${ }^{1}$

Berdasarkan data Depkes RI tahun 2010 bahwa kasus gizi kurang dan gizi buruk pada anak-anak kini menunjukkan penurunan. Pada tahun 2007 kasus gizi kurang dan gizi buruk sebanyak 5,1 juta, kemudian tahun 2008 sebanyak turun menjadi 4,42 juta, gizi buruk dan gizi kurang itu sekitar $10 \%$ berakhir dengan kematian. ${ }^{2}$

Berdasarkan data dari Dinas kesehatan Provinsi Sulawesi Selatan pada tahun 2013 bahwa balita yang mengalami kekurangan gizi sebanyak $213(10,6 \%)$ kasus nyata Kwashiorkor-marasmus dan $467 \quad(23,5 \%)$ KEP, dan anak balita secara prevalensi kurus adalah $13,3 \%$ pada anak laki-laki dan 10,9\% pada perempuan. Sedangkan prevalensi berat badan (BB) lebih pada laki-laki 9,5\% dan perempuan $6,4 \% .^{3}$

Anak usia 4-6 tahun merupakan usia anakanak masih rentan terhadap gangguan penyakit gizi dan infeksi sehingga pemberian makanan yang bergizi tetap menjadi perhatian orang tua, para pengasuh, dan pendidik di Sekolah. Berdasarkan hal tersebut maka peneliti tertarik melakukan penelitian tentang faktor yang berhubungan dengan status gizi anak di TK Islam H.M. Asyik Makassar.

\section{Metode Penelitian}

Jenis penelitian yang digunakan dalam penelitian ini adalah Observasional dengan pendekatan Cross Sectional Study yaitu untuk mengetahui faktor yang berhubungan dengan status gizi anak di TK Islam H.M. Asyik Makassar yang diamati pada periode waktu yang sama. Populasi dalam penelitian ini adalah semua anak yang ada di TK Islam H.M. Asyik Makassar sebanyak 69 anak. Sampel dalam penelitian ini adalah semua anak yang ada di TK Islam H.M. Asyik Makassar yang dipilih dengan cara Exhaustic Sampling (total sampel) sebanyak 69 anak.

Untuk mengetahui ada tidaknya hubungan antara variabel dependen dengan vareabel independen maka digunakan uji chi-square dengan tingkat keamanan $\alpha=0,05$.

\section{Hasil Penelitian}

\section{Analisis Univariat} Pengetahuan

Tabel 1. Distribusi Frekuensi Pengetahuan Pengasuh anak TK Islam H. M. Asyik Makassar

\begin{tabular}{clcc}
\hline No & Pengetahuan & Frekuensi & \% \\
\hline 1 & Cukup & 26 & 53,1 \\
2 & Kurang & 23 & 46,9 \\
& Total & 49 & 100 \\
\hline
\end{tabular}

Berdasarkan tabel 1 diatas dapat menunjukan bahwa dari 49 pengasuh anak TK yang memiliki pengetahuan cukup sebanyak $53,1 \%$, dan pengetahuan kurang sebanyak $46,9 \%$.

\section{Pendapatan}

Tabel 2. Distribusi Frekuensi Pendapatan Keluarga anak TK Islam H.M. Asyik Makassar

\begin{tabular}{clcc}
\hline No & Pendapatan & Frekuensi & \% \\
\hline 1 & Cukup & 32 & 65,3 \\
2 & Kurang & 17 & 34,7 \\
& Total & 49 & 100 \\
\hline
\end{tabular}


Berdasarkan tabel 2 diatas dapat menunjukan bahwa dari 49 kepala keluarga anak TK yang memiliki pendapatan cukup sebayak $65,3 \%$ dan pendapatan kurang sebanyak $34,7 \%$.

\section{Asupan Gizi}

Tabel 3. Distribusi Frekuensi Asupan Gizi

\begin{tabular}{clcc}
\multicolumn{3}{c}{ anak TK Islam H.M. } & Asyik Makassar \\
\hline No & Asupan Gizi & Frekuensi & \% \\
\hline 1 & Cukup & 27 & 55,1 \\
2 & Kurang & 22 & 49,9 \\
& Total & 49 & 100 \\
\hline
\end{tabular}

Berdasarkan tabel 3 diatas menunjukan bahwa dari 49 anak TK yang memiliki asupan gizi cukup sebanyak 55,1\%, dan asupan gizi kurang sebanyak 49,9\%.

\section{Analisis Bivariat}

Berdasarkan hasil penelitian hubungan jenis asupan gizi, pengetahuan dan pendapatan terhadap status gizi anak di TK Islam H. M. Asyik Makassar dapat dilihat dalam tabel 4, 5 dan 6 di bawah ini:

\section{Asupan Gizi}

Tabel 4. Hubungan Asupan Gizi dengan Status Gizi Anak di TK Islam H. M. Asyik Makassar

\begin{tabular}{llcccc}
\hline No & & \multicolumn{2}{c}{ Status Gizi } & Jumlah & $\begin{array}{c}p \text { - } \\
\text { value }\end{array}$ \\
\cline { 3 - 4 } & Asupan Gizi & Baik & Kurang & & \\
\hline 1. & Cukup & 24 & 3 & 27 & \\
2. & & $88,9 \%$ & $11,1 \%$ & $100 \%$ & \\
& Kurang & 9 & 13 & 22 & 0,000 \\
& & $40,9 \%$ & $59,1 \%$ & $100 \%$ & \\
& Jumlah & 33 & 16 & 49 & \\
& & $67,3 \%$ & $32,7 \%$ & $100 \%$ & \\
\hline
\end{tabular}

Tabel 4 menunjukan bahwa dari 27 anak TK yang memiliki asupan gizi cukup terdapat anak TK memiliki status gizi baik sebanyak $88,9 \%$ sedangkan dari 22 anak TK yang memiliki asupan gizi kurang terdapat anak TK memiliki status gizi baik sebanyak 40,9\%. Hasil analisis statistik diperoleh nilai $\mathrm{X}^{2}$ hitung $(12,690)$ $>\mathrm{X}^{2}$ tabel $(3,841)$ dan nilai $\mathrm{p}(0,000)<$ 0,05 , ini berarti asupan gizi berhubungan dengan status gizi anak TK Islam H. M. Asyik Makassar tahun 2018.

\section{Pengetahuan}

Tabel 5. Hubungan Pengetahuan dengan Status Gizi Anak di TK Islam H. M. Asyik Makassar

\begin{tabular}{llcccc}
\hline \multirow{2}{*}{ No } & & \multicolumn{2}{c}{ Status Gizi } & Jumlah & p-value \\
\cline { 3 - 4 } & Pengetahuan & Baik & Kurang & & \\
\hline 1. & Cukup & 24 & 2 & 26 & \\
& & $92,3 \%$ & $7,7 \%$ & $100 \%$ & \\
2. & \multirow{2}{*}{ Kurang } & 9 & 14 & 23 & 0,000 \\
& & $39,1 \%$ & $60,9 \%$ & $100 \%$ & \\
& \multirow{2}{*}{ Jumlah } & 33 & 16 & 49 & \\
& & $67,3 \%$ & $32,7 \%$ & $100 \%$ & \\
\hline
\end{tabular}

Tabel 5 menunjukan bahwa dari 26 pengasuh anak TK yang memiliki pengatahuan cukup terdapat anak TK yang memiliki status gizi baik sebanyak 
92,3\% sedangkan dari 23 pengasuh anak TK yang memiliki pengetahuan kurang terdapat anak TK memiliki status gizi baik sebanyak 39,1\%. Hasil analisis statistik di peroleh nilai $\mathrm{X}^{2}$ hitung $(15,693)>\mathrm{X}^{2}$ tabel $(3,841)$ dan nilai $\mathrm{p}(0,000)<0,05$, ini berarti pengetahuan pengasuh berhubungan dengan status gizi anak TK Islam H. M. Asyik Makassar tahun 2018.

\section{Pendapatan}

Tabel 6. Hubungan Pendapatan dengan Status Gizi Anak di TK Islam H.M. Asyik Makassar

\begin{tabular}{|c|c|c|c|c|c|}
\hline \multirow[t]{2}{*}{ No } & \multirow[b]{2}{*}{ Pendapatan } & \multicolumn{2}{|c|}{ Status Gizi } & \multirow[t]{2}{*}{ Jumlah } & \multirow[t]{2}{*}{$p$-value } \\
\hline & & Baik & Kurang & & \\
\hline \multirow[t]{2}{*}{1.} & Cukup & 30 & 2 & 32 & \\
\hline & & $93,8 \%$ & $6,2 \%$ & $100 \%$ & \\
\hline \multirow[t]{4}{*}{2.} & Kurang & 3 & 14 & 17 & 0,000 \\
\hline & & $17,6 \%$ & $82,4 \%$ & $100 \%$ & \\
\hline & Jumlah & 33 & 16 & 49 & \\
\hline & & $67,3 \%$ & $32,7 \%$ & $100 \%$ & \\
\hline
\end{tabular}

Tabel 6 menunjukan bahwa dari 32 kepala keluarga anak TK yang memiliki pendapatan cukup terdapat anak TK yang memiliki status gizi baik sebanyak 93,8\% sedangkan dari 17 kepala keluarga anak TK yang memiliki pendapatan kepala keluarga kurang terdapat anak TK memiliki status gizi baik sebanyak 17,6\%. Hasil analisis statistik di peroleh nilai $X^{2}$ hitung $(29,239)$ $>\mathrm{X}^{2}$ tabel $(3,841)$ dan nilai $\mathrm{p}(0,000)<$ 0,05 , ini berarti pendapatan kepala keluarga berhubungan dengan status gizi anak TK Islam H. M. Asyik Makassar tahun 2018.

\section{Pembahasan}

Asupan Gizi adalah semua jenis makanan dan minuman yang dikonsumsi tubuh setiap hari. Umumnya asupan makanan di pelajari untuk dihubungkan dengan keadaan gizi masyarakat suatu wilayah atau individu. Informasi ini digunakan untuk perencanaan pendidikan gizi khususnya untuk menyusun menu atau intervensi untuk peningkatan sumber daya manusia (SDM), mulai dari keadaan kesehatan dan gizi serta produktivitasnya. Mengetahui asupan makanan suatu kelompok masyarakat atau individu merupakan salah satu cara untuk menduga keadaan gizi kelompok masyarakat atau individu bersangkutan. ${ }^{4}$

Proses penelan makanan melibatkan dua disiplin ilmu yang sangat berbeda. Pertama, sebelum ditelan merupakan masalah perilaku yang berkaitan dengan keadaan sosial, ekonomi, budaya dan lingkungan. Kedua, setelah makanan ditelan merupakan proses metabolisme yang dimulai dari metabolisme sampai dampak dari asupan makanan, yang bersangkutan terhadap keadaan gizi. Di Indonesia pada saat ini juga terjadi pergeseran pola komsumsi atau asupan gizi masyarakat.

Hasil penelitian ini menunjukan bahwa dari 27 anak TK yang memiliki asupan gizi cukup terdapat anak TK memiliki status gizi baik sebanyak 88,9\% sedangkan dari 22 anak TK yang memiliki asupan gizi kurang terdapat anak TK memiliki status gizi baik sebanyak $40,9 \%$.

Hasil analisis statistik diperoleh nilai $\mathrm{X}^{2}$ hitung $(12,690)>X^{2}$ tabel $(3,841)$ dan nilai $p$ $(0,000)<0,05$, ini berarti asupan gizi berhubungan dengan status gizi anak TK Islam H. M. Asyik Makassar tahun 2018. 
Penelitian ini sesuai atau sejalan dengan penelitian yang dilakukan oleh Muhanmmad Fadili pada tahun 2005 bahwa ada hubungan asupan gizi dengan status gizi. Begitu pula dengan hasil penelitian Rahmat S tahun 2003 bahwa ada hubungan asupan gizi dengan status gizi. ${ }^{5}$

Menurut Heri Purwanto (1999), bahwa untuk terbentuknya suatu perilaku atau tindakan maka dibutuhkan pengetahuan. begitu juga pengaruh atau kaitan pengetahuan dengan status gizi, tanpa pengetahuan pengasuh yang cukup tentang cara pencapaian status gizi yang baik misalnya frekuensi makan anak yang benar, cara penyajian makanan yang benar serta status gizi anak yang seharusnya maka pengasuh tidak ada keinginan untuk memenuhi kebutuhan gizi anak. $^{6}$

Berbeda dengan hasil penelitian Manjilala dkk (2017) di Puskesmas Batua menunjukkan bahwa tidak ada hubungan antara asupan protein dengan status gizi balita $\mathrm{p}=(0,125)$, $\mathrm{PB} / \mathrm{U} \mathrm{p}=(0,380), \mathrm{BB} / \mathrm{PB} \mathrm{p}=(0,323){ }^{7}$

Pengetahuan yang dimaksud dalam penelitian ini adalah apa yang diketahui dan mampu di ingat oleh seseorang/responden mengenai pentingnya gizi bagi pertumbuhan anak. ${ }^{8}$ Hasil penelitian ini menunjukan bahwa dari 26 pengasuh anak TK yang memiliki pengatahuan cukup terdapat anak TK yang memiliki status gizi baik sebanyak 92,3\% sedangkan dari 23 pengasuh anak TK yang memiliki pengetahuan kurang terdapat anak TK memiliki status gizi baik sebanyak 39,1\%.

Hasil analisis statistik di peroleh nilai $\mathrm{X}^{2}$ hitung $(15,693)>X^{2}$ tabel $(3,841)$ dan nilai $p$ $(0,000)<0,05$, ini berarti pengetahuan pengasuh berhubungan dengan status gizi anak TK Islam H. M. Asyik Makassar tahun 2018.

Hasil penelitian ini sejalan dengan penelitian yang telah dilakukan oleh Sulvida di Taman kanak-kanak Aisyiyah Bustanul Layang utara kota Makassar 2004, yang menunjukan bahwa ada hubungan pengetahuan ibu dengan pertumbuhan anak dengan nilai $\mathrm{p}(0,004){ }^{9}$

Pendapatan merupakan salah satu factor determinan yang dapat mempengarui konsumsi makanan dalam keluarga, seperti yang dikemukakan dalam hukum Periisse yang mengatakan bahwa jika terjadi kenaikan pendapatan, makanan yang dibeli akan lebih bervariasi atau berubah.

Hasil penelitian ini menunjukan bahwa dari 32 kepala keluarga anak TK yang memiliki pendapatan cukup terdapat anak TK yang memiliki status gizi baik sebanyak 93,8\% sedangkan dari 17 kepala keluarga anak TK yang memiliki pendapatan kepala keluarga kurang terdapat anak TK memiliki status gizi baik sebanyak $17,6 \%$.

Hasil analisis statistik di peroleh nilai $\mathrm{X}^{2}$ hitung $(29,239)>X^{2}$ tabel $(3,841)$ dan nilai $p$ $(0,000)<0,05$, ini berarti pendapatan kepala keluarga berhubungan dengan status gizi anak TK Islam H. M. Asyik Makassar tahun 2018.

Hasil penelitian ini sesuai dengan penelitian yang telah dilakukan oleh Ngatimin tahun 1997 bahwa sesuai dengan yang meningkatkan pendapatan akan membawa barang-barang yang masyarakat membelanjakan penghasilannya untuk barang-barang yang dipasarkan, baik untuk menunjang upaya peningkatan gizi berupa makanan bergizi, bahan-bahan untuk perbaikan sanitasi serta usaha untuk mendapatkan pengobatan dini dikala sakit. ${ }^{10}$

\section{Kesimpulan}

1. Asupan gizi berhubungan dengan status gizi anak TK Islam H. M. Asyik Makassar.

2. Pengetahuan pengasuh berhubungan dengan status gizi anak TK Islam H. M. Asyik Makassar. 
3. Pendapatan kepala keluarga berhubungan dengan status gizi anak TK Islam H. M. Asyik Makassar.

\section{Saran}

1. Bagi ibu dan pengasuh sebaiknya lebih menambah pengetahuan mengenai gizi anak dan keluarga serta lebih memperhatikan asupan makanan yang di komsumsi oleh anak, agar status gizi anak berada dalam ketegori status gizi baik.

2. Bagi pihak sekolah sebaiknya sekali dalam seminggu memberikan makanan tambahan bagi anak murid, seperti bubur kacang merah, bubur kacang ijo. Agar dapat membantu perbaikan status gizi anak.

3. Bagi peneliti selanjutnya agar meneliti lebih dalam, lebih rinci mengenai faktor yang mempengaruhi status gizi dengan pertumbuhan anak.

\section{Daftar Pustaka}

1. WHO/UNICEF, 2012. All About Nutrition. http://iinaza.wordpress.com (online) (Diakses tanggal 19 Februari 2015).

2. Depkes RI, 2013. Pedoman Pembinaan Kesehatan Anak Sekolah. Jakarta

3. Riskesdas Makassar, 2014. Komposisi Zat Gizi Makanan Indonesia. Direktorat Bina Gizi Masyarakat. Makassar : Proyek Perbaikan Gizi Masyarakat Sulsel.

4. Suhardjo, 2009. Perencanaan Pengan dan Gizi, Bagian Pertama. Jakarta. Bumi Aksara.

5. Muhammad Fadili.2005. Hubungan Asupan Gizi Mikro Dengan Status Gizi Siswa Sd Inpres 2 Pannampu Kecamatan Tallo Kota Makassar. Skripsi.

6. Purwanto, Heri. 1998. Pengantar Perilaku Manusia. Jakarta: EGC.

7. Manjilala, Donna Inrivianthy, Fatmawaty Suaib. 2017. Hubungan Asupan Zat Gizi Protein Dengan Status Gizi Balita Usia 624 Bulan Di Rw 2 Wilayah Puskesmas
Batua Kota Makassar. Media Gizi Pangan, Vol. XXIV, Edisi 2.

8. Notoatmodjo, Soekidjo. 2007. Promosi Kesehatan dan Ilmu Perilaku. Jakarta: Rineka Cipta.

9. Sulvida. 2004. Hubungan Pengetahuan Ibu dengan Pertumbuham Anak. di Taman kanak-kanak Aisyiyah Bustanul Layang utara kota Makassar 2004. Skripsi.

10. Ngatimin. 1997. Antropologi dan perilaku kesehatan. Disertasi. 